\title{
The Effect of Hydration on Promoting Oxidative Reactions with Aluminum Oxide and Oxyhydroxide Nanoparticles
}

I. Shancita ${ }^{1}$, Loudon Lee Campbell ${ }^{\mathrm{a}}$, Chi-Chin $\mathrm{Wu}^{\mathrm{b} *}$, Adelia J.A. Aquino ${ }^{\mathrm{c}, \mathrm{d}^{*}}$, Scott D. Walck ${ }^{\mathrm{e}}$, Daniel Tunega ${ }^{\mathrm{d}^{*}}$, Michelle L. Pantoya ${ }^{\mathrm{a}^{*}}$

a Department of Mechanical Engineering, Texas Tech University, Lubbock, Texas 79409, USA

${ }^{\mathrm{b}}$ Lethality Division, Weapons and Materials Research Directorate, U.S. Army Research

Laboratory, Aberdeen Proving Ground, Maryland 21005, USA

c Department of Chemistry and Biochemistry, Texas Tech University, Lubbock, Texas 79409-1061, USA

d Institute for Soil Research, University of Natural Resources and Life Sciences, Peter-JordanStrasse 82, Wien A-1190, Austria

eSurvice Engineering Co., U.S. Army Research Laboratory, Aberdeen Proving Ground, Maryland 21005, USA

\section{Supplementary Information}

Table of Contents

S1. Stoichiometry and lateral vectors of the computational unit cells of the periodic

slab models of $\gamma-\mathrm{Al}_{2} \mathrm{O}_{3}$ and boehmite used in the VASP calculations...........Page S2

S2. Characterization of starting $\gamma-\mathrm{Al}_{2} \mathrm{O}_{3}$ and $\gamma-\mathrm{AlO}(\mathrm{OH})$ materials via XRD and TEM Page S3

S3. X-ray Elemental Diffraction Spectra (XEDS) from $\gamma$-AlO $(\mathrm{OH}) / \mathrm{AIH}$

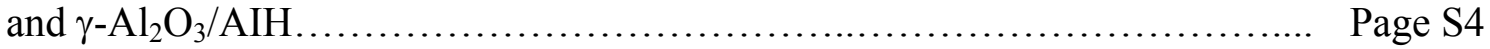

S4. Disappearance of iodine from the $\gamma-\mathrm{Al}_{2} \mathrm{O}_{3} / \mathrm{AIH}$ sample $\ldots \ldots \ldots \ldots \ldots \ldots \ldots \ldots \ldots$ Page S4

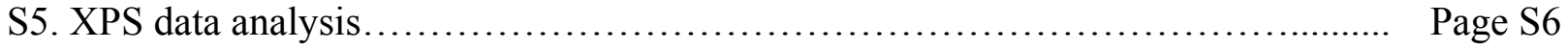

* Corresponding authors:

Email address: michelle.pantoya@ttu.edu (M.L. Pantoya); adelia.aquino@ttu.edu (A.Aquino);

daniel.tunega@univie.ac.at (D. Tunega); Chi-chin.wu.civ@mail.mil (C.C.Wu) 
S1. Stoichiometry and lateral vectors of the computational unit cells of the periodic slab models of $\gamma-\mathrm{Al}_{2} \mathrm{O}_{3}$ and boehmite used in the VASP calculations

Table S1. Stoichiometry and lateral vectors of the computational unit cells of the periodic slab models of $\gamma-\mathrm{Al}_{2} \mathrm{O}_{3}$ and boehmite used in the VASP calculations. The cell vector $c$ is not shown as it slightly varied at around $30 \AA$ within a margin of $\sim 1 \AA$, depending on the thickness of the particular slab model at a constant vacuum of $20 \AA$ above the slab.

\begin{tabular}{|l|l|c|c|c|}
\hline Model/site or surface & Figure & Stoichiometry & $\boldsymbol{a}(\AA)$ & $\boldsymbol{b}(\AA)$ \\
\hline$\gamma-\mathrm{Al}_{2} \mathrm{O}_{3} / \mathrm{Ia}, \mathrm{IIa}, \mathrm{IIb}, \mathrm{III}$ & Fig. 1a,c,d,e & $\mathrm{Al}_{36} \mathrm{O}_{64} \mathrm{H}_{20}$ & 11.226 & 9.722 \\
\hline$\gamma-\mathrm{Al}_{2} \mathrm{O}_{3} / \mathrm{Ib}$ & Fig. 1b & $\mathrm{Al}_{35} \mathrm{O}_{64} \mathrm{H}_{23}$ & 11.226 & 9.722 \\
\hline boehmite/(001) & Fig. 2a & $\mathrm{Al}_{36} \mathrm{O}_{84} \mathrm{H}_{60}$ & 12.107 & 8.697 \\
\hline boehmite/(010) & Fig. 2b & $\mathrm{Al}_{36} \mathrm{O}_{72} \mathrm{H}_{36}$ & 11.095 & 8.692 \\
\hline boehmite/(100) & Fig. 2c & $\mathrm{Al}_{36} \mathrm{O}_{96} \mathrm{H}_{84}$ & 12.004 & 11.085 \\
\hline
\end{tabular}




\section{S2. Characterization of starting $\gamma-\mathrm{Al}_{2} \mathrm{O}_{3}$ and $\gamma-\mathrm{AlO}(\mathrm{OH})$ materials via XRD and TEM}

Figure S1 represents the PXRD scans for alumina and boehmite starting materials to evaluate the purity of the materials by the deviations of peak positions from their respective theoretical values. The $\gamma-\mathrm{Al}_{2} \mathrm{O}_{3}$ and $\gamma-\mathrm{AlO}(\mathrm{OH})$ crystalline structures are pure. Also shown in Fig. S1 are the TEM images for both materials.
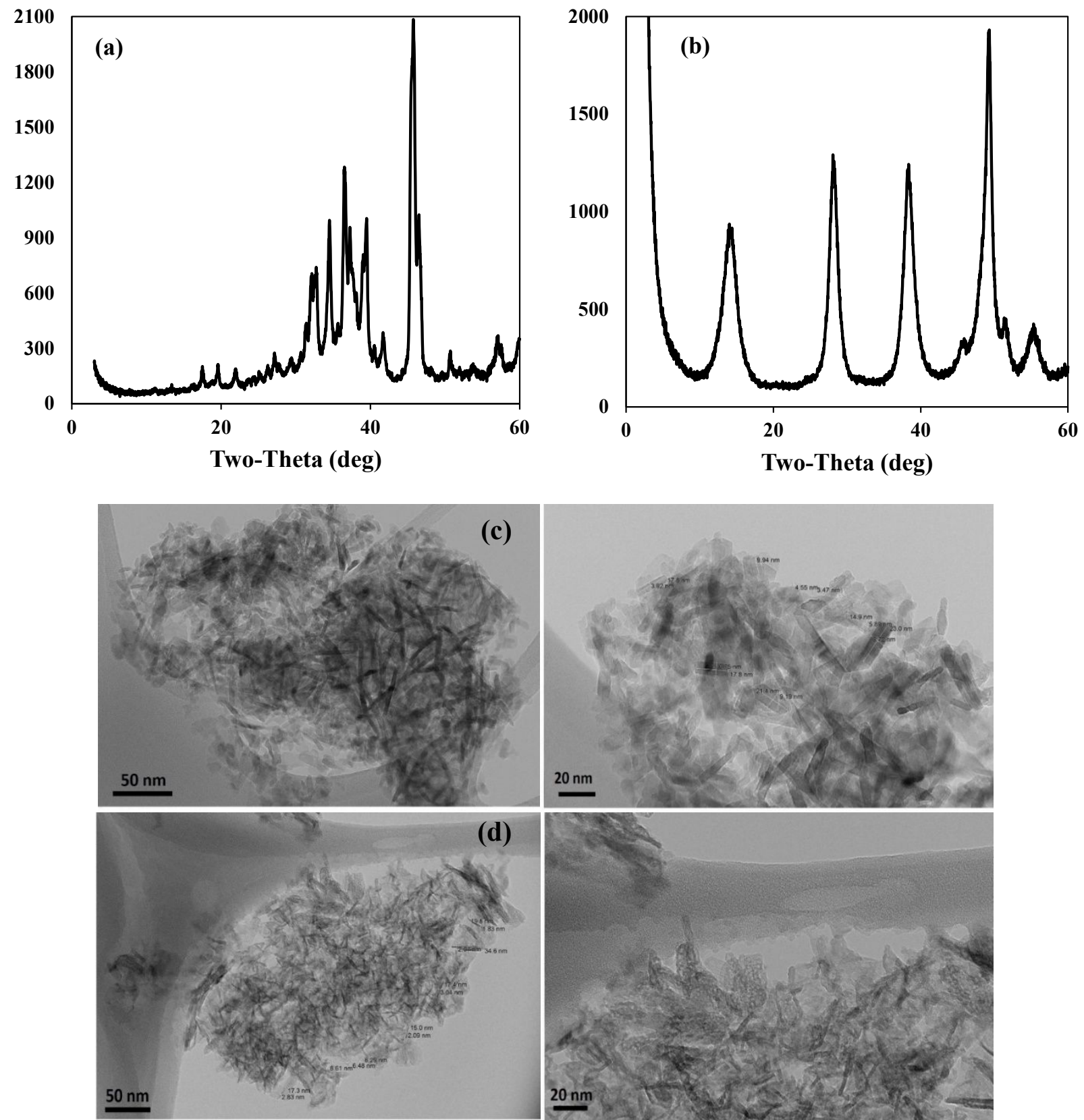

Figure S1. PXRD pattern of (a) $\gamma-\mathrm{Al}_{2} \mathrm{O}_{3}$; (b) $\gamma$ - $\mathrm{AlO}(\mathrm{OH})$; and, TEM images of (c) $\gamma-\mathrm{Al}_{2} \mathrm{O}_{3}$ (d) $\gamma$ $\mathrm{AlO}(\mathrm{OH})$. 
S3. X-ray Elemental Diffraction Spectra (XEDS) from $\gamma$-AIOOH/AIH and $\gamma$ - $\mathrm{Al}_{2} \mathrm{O}_{3} / \mathrm{AIH}$.

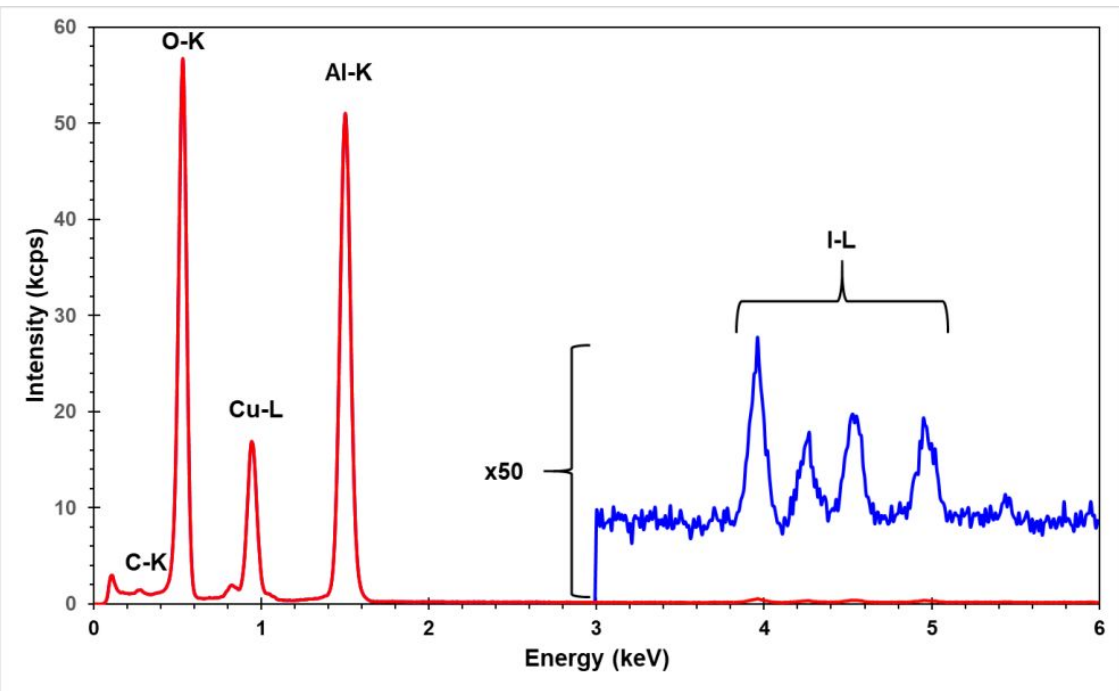

Figure S2. The cumulative XEDS spectrum of the spectrum image for the area corresponding to Fig. 4 for $\mathrm{AlO}(\mathrm{OH}) / \mathrm{AIH}$ sample is shown in red. The blue curve is the intensities above $3 \mathrm{keV}$ rescaled by a factor of 50 to better show the iodine peaks.

\section{S4. Disappearance of iodine from the $\gamma-\mathrm{Al}_{2} \mathrm{O}_{3} / \mathrm{AIH}$ sample}

Figure $\mathbf{S} 3$ show particles with their corresponding spectra before and after the region of interest is exposed to a condensed electron beam in TEM for a few minutes. The enlarged images clearly show the removal of the iodine-rich phase at the surface of the particles. 

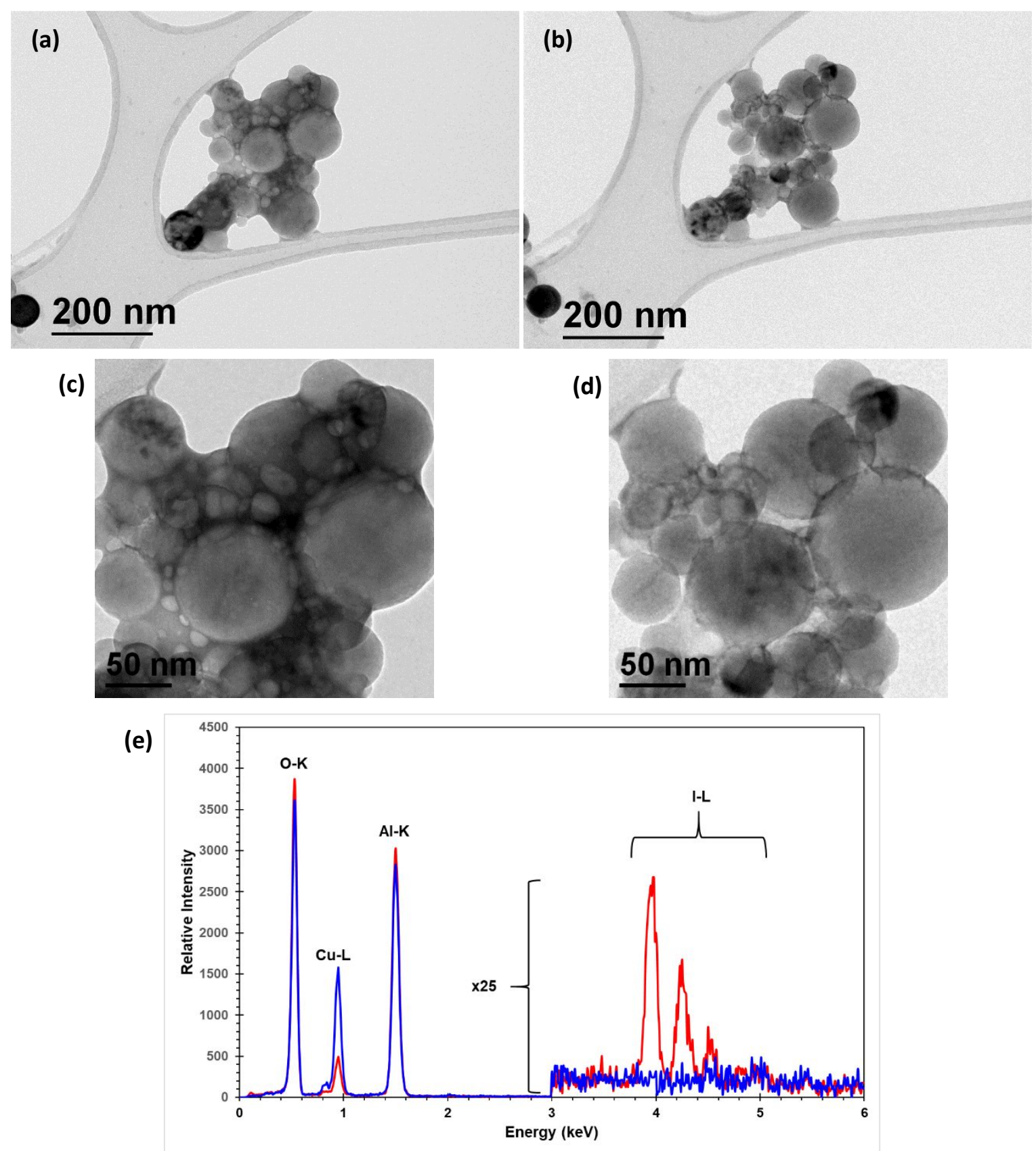

Figure S3. TEM images of $\gamma-\mathrm{Al}_{2} \mathrm{O}_{3} / \mathrm{AIH}$ nanoparticles (a) before (top left) and (b) after (top right) exposure to a condensed electron beam; (c) and (d) Enlarged images of (a) and (b), respectively, (e) Overlaid XEDS spectra acquired from the same area before (red) and after (blue) exposure that shows the disappearance of iodine after exposure. The intensities above 3 $\mathrm{keV}$ are scaled by a factor of 25 to better see the I-L lines. 


\section{S5. XPS data analysis}

Figure S4 represents the X-ray photoelectron spectroscopy (XPS) general survey scans for $\mathrm{AIH}$ synthesized from both $\mathrm{Al}_{2} \mathrm{O}_{3}$ and $\mathrm{AlO}(\mathrm{OH})$ nanoparticles. The corresponding atomic percentages $(\mathrm{AC} \%)$ of all strong photopeaks are listed in Table S1, which confirms the presence of iodine after dissolving of $\mathrm{Al}_{2} \mathrm{O}_{3}$ and $\mathrm{AlO}(\mathrm{OH})$ nanoparticles in iodic acid to form $\mathrm{AIH}$.

The $\mathrm{O} 1 \mathrm{~s}$ and $\mathrm{I} 3 \mathrm{~d} 5 / 2$ photopeak scans for $\mathrm{Al}_{2} \mathrm{O}_{3}$ and $\mathrm{AlO}(\mathrm{OH})$ nanoparticles and $\mathrm{AIH}$ synthesized from those particles are presented in Figures S5 and S6. The I 3d5/2 photopeak in Fig. S6 corresponds to anhydrous $\mathrm{I}_{2} \mathrm{O}_{5}$ as well as hydrated $\mathrm{HI}_{3} \mathrm{O}_{8}$ and $\mathrm{HIO}_{3}$. The XPS survey scans for $\gamma-\mathrm{Al}_{2} \mathrm{O}_{3}$ and $\gamma-\mathrm{AlO}(\mathrm{OH})$ nanoparticles and the $\mathrm{C} 1 \mathrm{~s}$ and $\mathrm{Al} 2 \mathrm{p}$ photopeaks of $\gamma-\mathrm{Al}_{2} \mathrm{O}_{3}$ and $\gamma-\mathrm{AlO}(\mathrm{OH})$ nanoparticles and for $\mathrm{AIH}$ synthesized from both $\gamma-\mathrm{Al}_{2} \mathrm{O}_{3}$ and $\gamma-\mathrm{AlO}(\mathrm{OH})$ nanoparticles including their corresponding AC\% are provided in Figs. S7-S9, respectively.
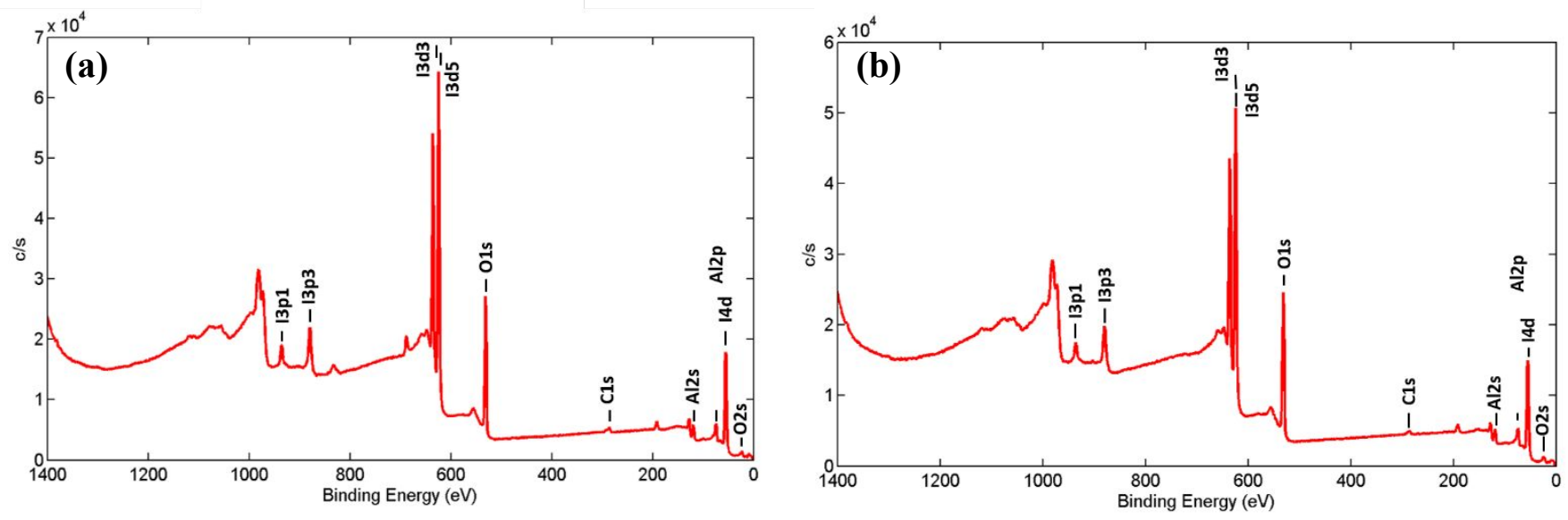

Figure S4. X-ray Photoelectron Spectroscopy (XPS) survey scans for $11 \mathrm{wt} \%$ of AIH synthesized on: (a) $\gamma-\mathrm{Al}_{2} \mathrm{O}_{3}$; (b) $\gamma-\mathrm{AlO}(\mathrm{OH})$.

Table S2. Atomic concentration percentages ( $\mathrm{AC} \%$ ) measured with XPS for $\mathrm{Al}_{2} \mathrm{O}_{3}$ and $\mathrm{AlO}(\mathrm{OH})$ precursor powders and their corresponding $\mathrm{AIH}$ containing counterparts.

\begin{tabular}{cccccc}
\hline Materials & \multicolumn{5}{c}{ Atomic Concentrations (AC\%) } \\
& $\mathrm{C} 1 \mathrm{~s}$ & $\mathrm{O} 1 \mathrm{~s}$ & $\mathrm{Al} 2 \mathrm{p}$ & $\mathrm{I} 3 \mathrm{~d} 5 / 2$ & $\mathrm{~F} 1 \mathrm{~s}$ \\
& & & & \\
\hline$\gamma-\mathbf{A l}_{\mathbf{2}} \mathbf{O}_{3}$ & 7.4 & 62.0 & 30.5 & - & - \\
$\gamma-\mathbf{A l}_{\mathbf{2}} \mathbf{O}_{3} / \mathbf{A I H}$ & 8.7 & 50.9 & 22.5 & 11.8 & 5.7 \\
\hline$\gamma-\mathbf{A l O}(\mathbf{O H})$ & 5.7 & 68.7 & 25.6 & - & - \\
$\gamma-\mathbf{A l O}(\mathbf{O H}) / \mathbf{A I H}$ & 4.3 & 59.3 & 24.9 & 11.5 & - \\
\hline
\end{tabular}



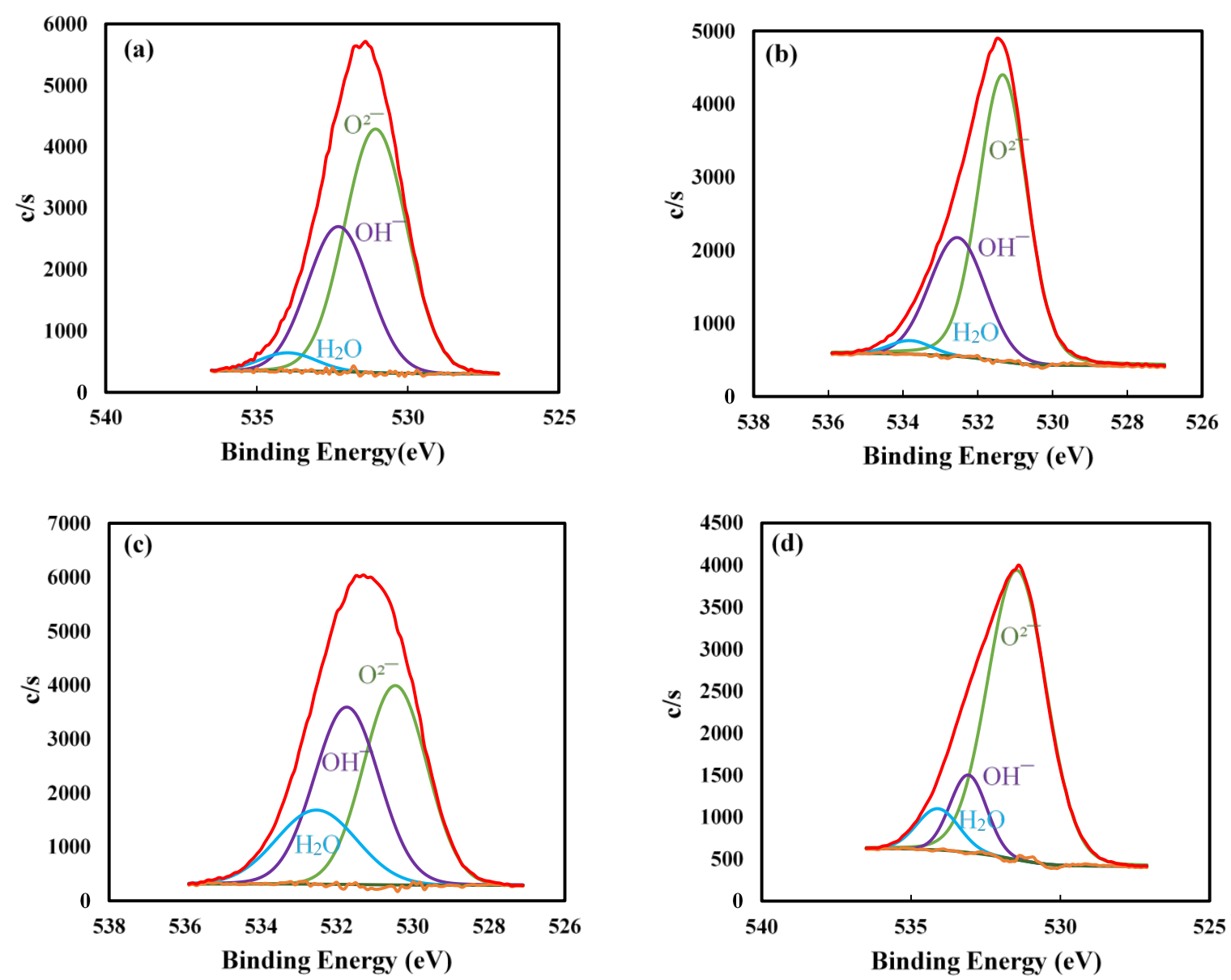

Figure S5. O 1s photopeak for (a) $\gamma-\mathrm{Al}_{2} \mathrm{O}_{3}$; (b) $\gamma-\mathrm{Al}_{2} \mathrm{O}_{3} / \mathrm{AIH}$; (c) $\gamma-\mathrm{AlO}(\mathrm{OH})$; (d) $\gamma$ $\mathrm{AlO}(\mathrm{OH}) / \mathrm{AIH}$. Green, purple and blue lines represent $\mathrm{O}^{2-}, \mathrm{OH}^{-}$and $\mathrm{H}_{2} \mathrm{O}$, respectively. 

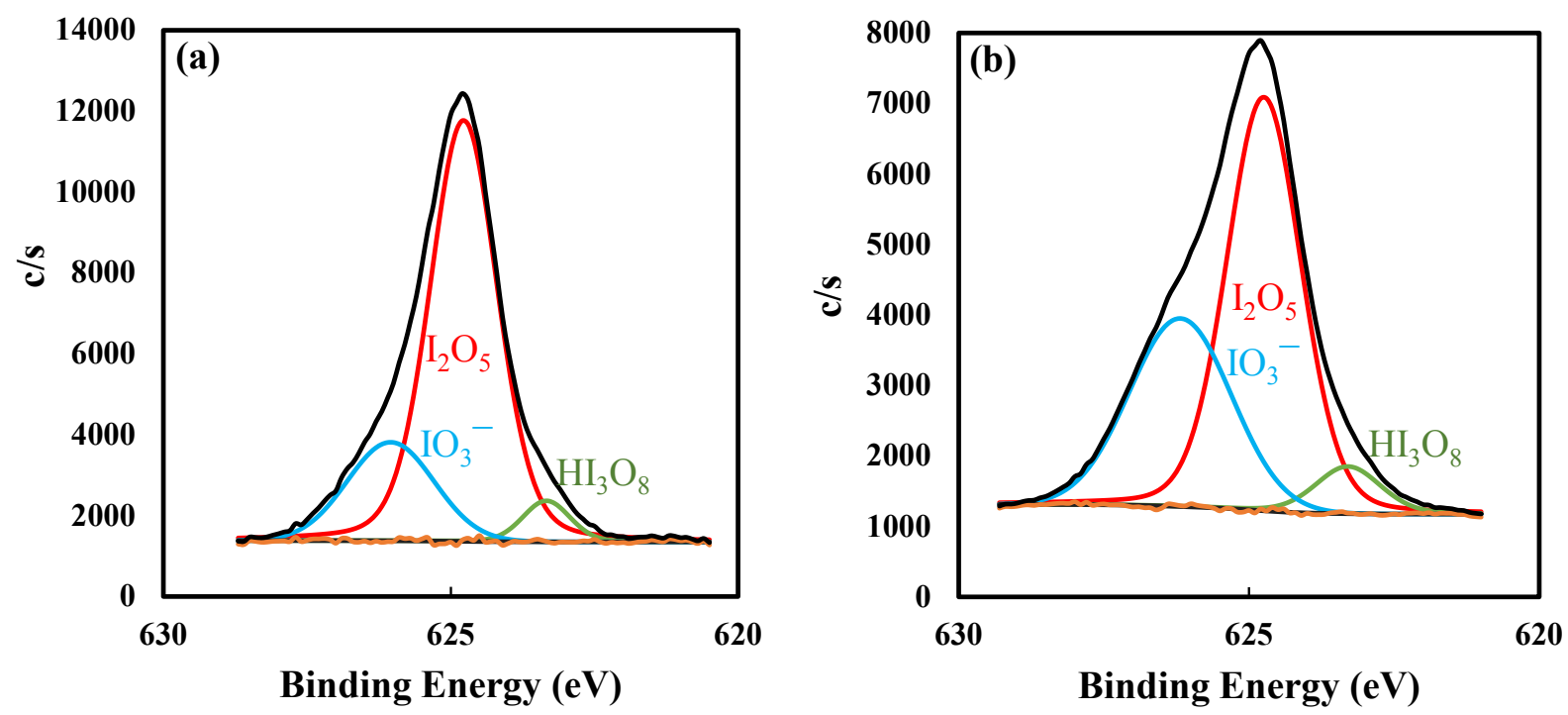

Figure S6. I3d5/2 photopeak for (a) $\gamma-\mathrm{Al}_{2} \mathrm{O}_{3} / \mathrm{AIH}$; \& (b) $\gamma-\mathrm{AlO}(\mathrm{OH}) / \mathrm{AIH}$. Green, red and blue lines stand for $\mathrm{HI}_{3} \mathrm{O}_{8}, \mathrm{I}_{2} \mathrm{O}_{5}$ and $\mathrm{IO}_{3}{ }^{-}$, respectively.

Figure $\mathbf{S} 7$ shows the XPS survey scans for $\gamma-\mathrm{Al}_{2} \mathrm{O}_{3}$ and $\gamma-\mathrm{AlO}(\mathrm{OH})$ samples. Moreover, the deconvoluted curves of $\mathrm{C} 1 \mathrm{~s}$ for $\gamma-\mathrm{Al}_{2} \mathrm{O}_{3}$ and $\gamma-\mathrm{AlO}(\mathrm{OH})$ with $\mathrm{AIH}$ are presented in Figure S8. All the samples have $\mathrm{C} 1 \mathrm{~s}, \mathrm{O} 1 \mathrm{~s}$ and $\mathrm{Al} 2 \mathrm{p}$ photopeak including I $3 \mathrm{~d} 5 / 2$ photopeak for AIH samples. Figure $\mathbf{S 9}$ represents $\mathrm{Al} 2 \mathrm{p}$ photopeaks of parent materials - a) $\gamma-\mathrm{Al}_{2} \mathrm{O}_{3}$ and c) $\gamma-\mathrm{AlO}(\mathrm{OH})$, and reaction products b) $\gamma-\mathrm{Al}_{2} \mathrm{O}_{3} / \mathrm{AIH}$ and d) $\gamma-\mathrm{AlO}(\mathrm{OH}) / \mathrm{AIH}$, respectively. $\mathrm{Al} 2 \mathrm{p}$ photopeaks of the reaction products have more complex structure with broadening and higher asymmetry compared to parent materials indicating a presence of $\mathrm{Al}$ in different chemical species - e.g. $\left[\mathrm{Al}\left(\mathrm{H}_{2} \mathrm{O}\right)_{6}\right]^{3+}$ of $\mathrm{AIH}$ or $\mathrm{Al}(\mathrm{OH})_{3}$.
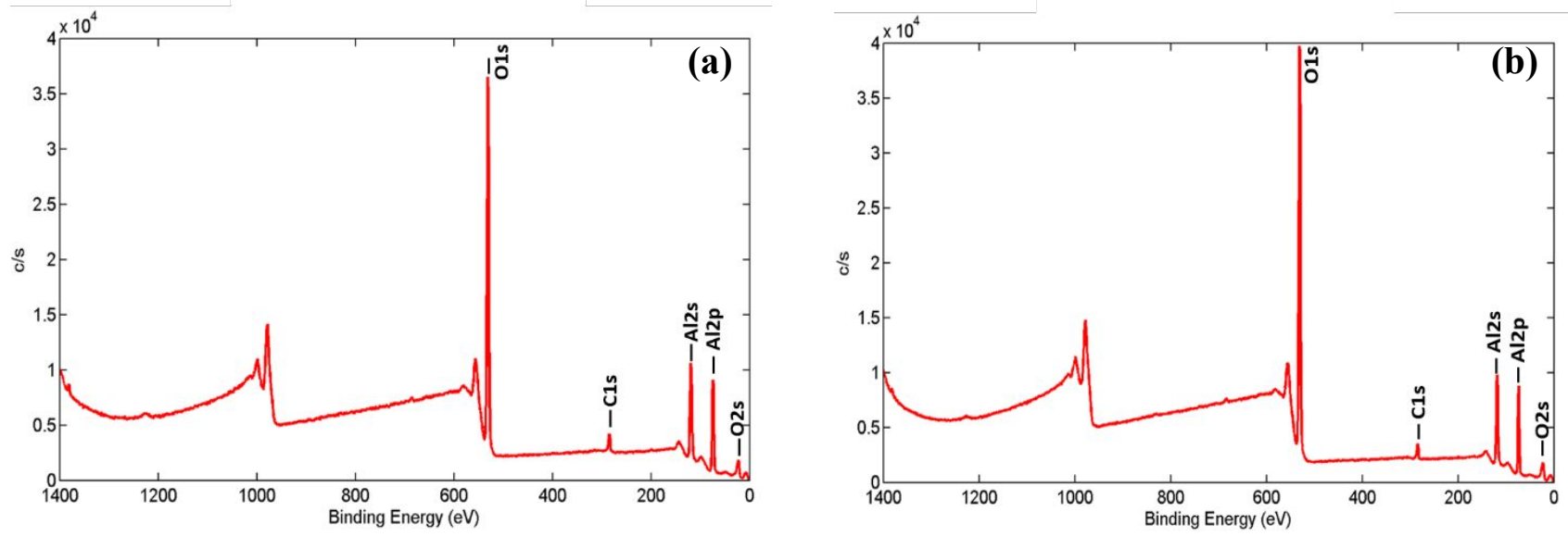

Figure S7. XPS survey scans of (a) $\gamma-\mathrm{Al}_{2} \mathrm{O}_{3}$; \& (b) $\gamma-\mathrm{AlO}(\mathrm{OH})$ 

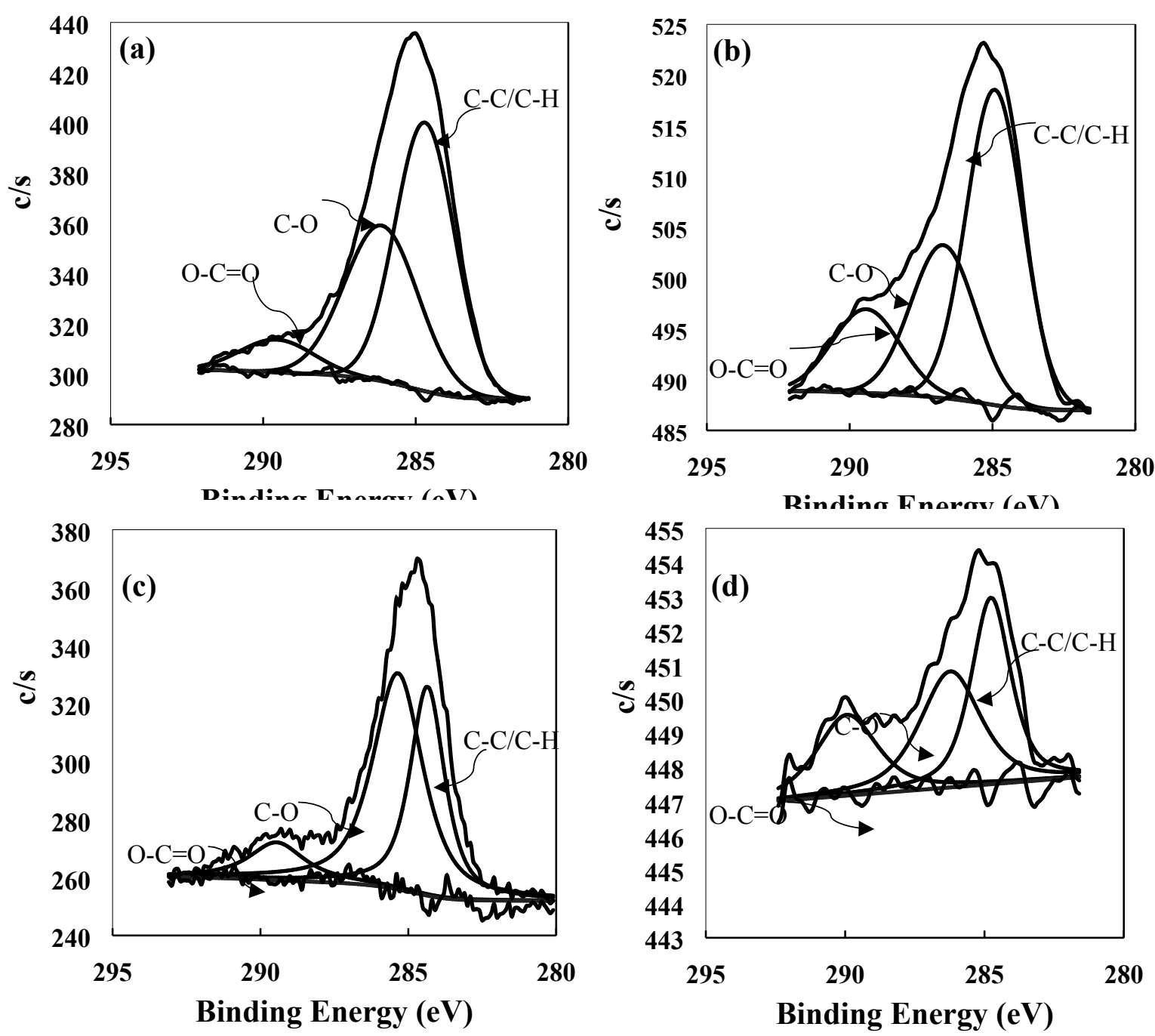

Figure S8. C 1 s photopeak for the following samples: (a) $\gamma-\mathrm{Al}_{2} \mathrm{O}_{3}$; (b) $\gamma-\mathrm{Al}_{2} \mathrm{O}_{3} / \mathrm{AIH}$; (c) $\gamma$ $\mathrm{AlO}(\mathrm{OH})$; and, (d) $\gamma$-AlO $(\mathrm{OH}) / \mathrm{AIH}$ 

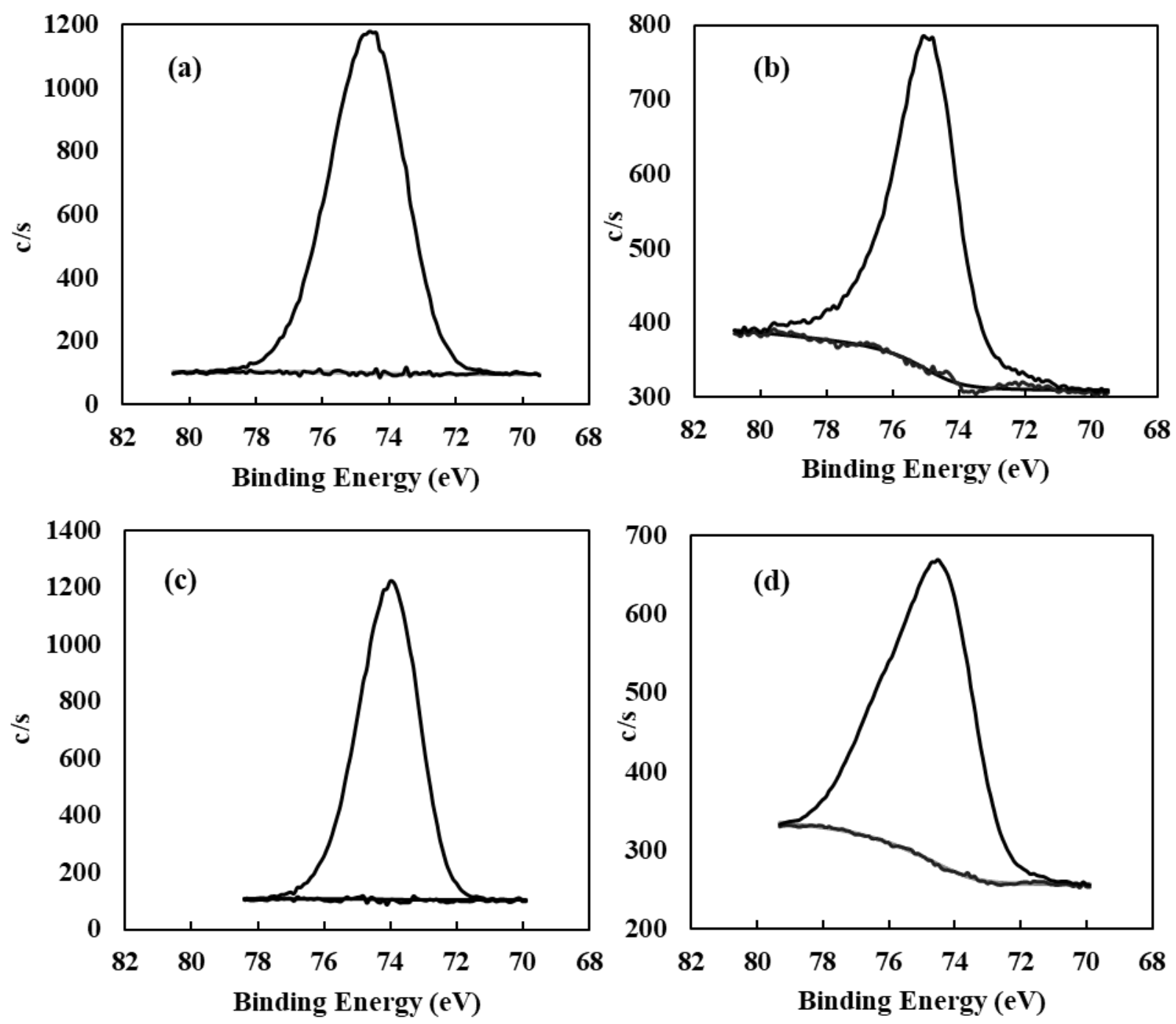

Figure S9. Al 2p photopeak for the following samples: (a) $\gamma-\mathrm{Al}_{2} \mathrm{O}_{3}$; (b) $\gamma-\mathrm{Al}_{2} \mathrm{O}_{3} / \mathrm{AIH}$; (c) $\gamma$ $\mathrm{AlO}(\mathrm{OH})$; and, (c) $\gamma$-AlO $(\mathrm{OH}) / \mathrm{AIH}$

For the $\mathrm{C} 1 \mathrm{~s}$ photopeak, all carbon is from environmental contamination in every sample and obvious to detect with XPS. The $\mathrm{C}-\mathrm{O}$ and $\mathrm{O}-\mathrm{C}=\mathrm{O}$ peaks correspond to the conterminous carbon bonded with oxygen from environment or from another oxygen containing species presented in those samples and their corresponding binding energies (BE) are listed in Table S2. 
Table S3. Atomic concentration percentages (AC\%) of XPS C 1s spectra

\begin{tabular}{|c|c|c|c|}
\hline Materials & C-C (BE $284.8 \mathrm{eV})$ & $\begin{array}{c}\text { C-O (BE 286-287 } \\
\text { eV) }\end{array}$ & $\begin{array}{c}\text { O-C=O (BE 289-290 } \\
\text { eV) }\end{array}$ \\
\hline & $\mathrm{AC} \%$ & $\mathrm{AC} \%$ & $\mathrm{AC} \%$ \\
\hline$\gamma-\mathbf{A l}_{2} \mathbf{O}_{3}$ & 48.91 & 37.88 & 13.22 \\
\hline$\gamma-\mathbf{A l}_{2} \mathbf{O}_{3} / \mathbf{A I H}$ & 51.01 & 30.15 & 18.84 \\
\hline$\gamma-\mathrm{AIO}(\mathrm{OH})$ & 33.65 & 49.95 & 16.41 \\
\hline$\gamma$-AIO(OH)/AIH & 41.46 & 38.75 & 19.79 \\
\hline
\end{tabular}

